\title{
A Review on Oil Spill Clean-up Using Bio-Sorbent Materials with Special Emphasis on Utilization of Kenaf Core Fibers
}

\author{
Jen Yen Tan, ${ }^{\mathrm{a}}$ Siew Yan Low, ${ }^{\mathrm{a}}$ Zhen Hong Ban, ${ }^{\mathrm{a}, \mathrm{b}}$ and Parthiban Siwayanan ${ }^{\mathrm{a}, \mathrm{b}, *}$
}

Thousands of oil spill incidents regrettably have occurred on a daily basis around the globe. Oil spills are a form of pollution that poses major catastrophic threats to marine ecosystems. Oil spill incidents commonly occur in the middle of the ocean, and the process to remove the oil becomes a great challenge. Absorbents, due to their good oil-absorbing characteristics, are becoming more popular nowadays as one of the effective oil spill clean-up methods. Among the many types of oil absorbents, plant fibers were also being studied to remove the oil spills from the sea surface. This paper reviews factors leading to oil spills, the detrimental effect of the oil spill on the environment, the oil spill removal methods, and the application of plant fibers as oil absorbent material. The paper also will highlight the latest development on the utilization of kenaf core fibers as oil-absorbent material and the use of oil absorbed kenaf core fibers as fuel briquette by taking advantage the high calorific value of the oil spill.

Keywords: Oil spill; Marine pollution; Oil sorbents; Kenaf core fiber

Contact information: a: School of Energy and Chemical Engineering, Xiamen University Malaysia Jalan Sunsuria, Bandar Sunsuria, 43900 Sepang, Selangor, MALAYSIA; b: College of Chemistry and Chemical Engineering, Xiamen University, Xiamen 361005, Fujian, CHINA;

* Correspondence to: parthiban.siwayanan@xmu.edu.my

\section{INTRODUCTION}

\section{Factors Causing Marine Oil Spills}

In recent years, the world still revolves around fossil fuel products, especially petroleum derivatives. These fossil fuel products require transportation using sea routes. Unfortunately, some accidents such as tanker wrecks and oil exploration release a large amount of oil into the sea and cause a huge impact on the marine ecosystem. Marine species such as birds and marine invertebrates are life-threatened by such accidents, not to mention clean-up work that is intensively carried out requires huge amount of manpower (AlonsoAlvarez et al. 2007; Aguilera et al. 2010).

The Deepwater Horizon oil spill that occurred in 2012 spilled 4 million barrels of oil into the sea and caused irreversible damage to the environment. The spilled oil even reached the wetlands of Louisiana in the United States and damaged the wetland ecosystem. It is estimated that hundreds of thousands of seabirds died due to starving and drowning, as their feathers were coated with oil (Balmer 2014; Potenza 2016). There is a decreasing trend on oil spills due to the increasing awareness of safety management and technical inspection on oil tankers. Despite that, there is room for improvements to be made regarding oil spill governance. In Malaysia, the amount of crude oil and petroleum products that are transported through the Strait of Malacca is increasing steadily throughout the years

Tan et al. (2021). "Oil spill clean-up with bio-sorbents," BioResources 16(4), 8394-8416. 8394 
(Villar and Hamilton 2017). Sources for oil spills include oil and gas exploration, transportation and storage, oil tanker accidents and leakages, accidents during ship loading/discharging, ship ballasting/de-ballasting, bunkering, discharging effluent from the petrochemical industry, or bursting pipelines (Ossai et al. 2020). Most of the oil spillages are occurring in the Atlantic Ocean, as the ship routes are concentrated there. Complex water situations can be caused by collision between oil tankers or ships, technical errors, bad weather, fire accidents due to electrical sparks, or wrong decisions made by the authorities (Galieriková and Materna 2020). The shipping industry is prone to oil spills. An analysis done by Chen et al. (2018) shows that an oil spill easily can occur during refuelling operations, causing ignition of fire and explosion. In the event of anchoring in open water or inland water, the ships are highly prone to collision. Other than that, the failing operating equipment and fire/explosion during cargo loading/unloading are crucial factors contributing to oil spillage.

\section{Effects of Marine Oil Spill to Environment}

Oil spills impose adverse impacts on aquatic life, threaten fisheries, and lead to loss of jobs. For example, the mode of nutrition of shellfish will lead to biological accumulation of oil spills particulates and/or chemicals in the oil spill area (Ferguson et al. 2020). When petroleum hydrocarbon enters the water, higher molecular weight hydrocarbons will sink to the bottom while the lighter and less viscous crude oil will float on the water surface. Weathering process will spread, evaporate, disperse, or cause emulsification to the oil, affecting the spreading rate of the thin surface films and slicks (Mishra and Kumar 2015).

Different composition of the petroleum hydrocarbon imposes different effects on the environment. Polycyclic aromatic hydrocarbons (PAHs) are one of the components in oil spills. PAHs are toxic and have mutagenic and/or carcinogenic properties. As they are highly lipid soluble, they are readily absorbed from the gastrointestinal tract when accidentally consumed by the aquatic life (Abdel-Shafy and Mansour 2016). Other components present include straight and branched chain alkanes, alkenes, alkynes, sulphur compound, oxygen compound, nitrogen compound, and certain metals. These components cause health effect such as haemotoxicity, mutagenicity, and cytotoxicity to humans who consume contaminated seafood (Ossai et al. 2020).

\section{Marine Oil Waste Removal Techniques/ Technologies/ Processes}

Physical removal of oil waste is one of the available methods. An oil skimmer is capable of collecting and removing a variety of oil on the water (Song et al. 2015). Containment booms are applied on the oil spill area to confine or prevent it from spreading to other areas. They can be used to change the direction flow or concentrate the oil spill for further action such as burning (Fingas 2011). In-situ burning is suitable for application in severe oil spill events to burn and remove the oil from the water surface at high rate and efficiency. Biological methods include biodegradation and bioremediation of oil spill by applying microorganisms to degrade the hydrocarbon in the target area (Atlas and Atlas 1991). Dispersants is another class of chemical that can be used for oil spill treatment. Detergent-like products are applied onto the layers of oil and diffuse to the oil/water interface. As a result, the surface tension between oil and water droplets are broken, hence the oil-water layers can be scattered into tiny droplets (Lessard and DeMarco 2000). Other methods include coagulation, flocculation, coalescences, membrane filtration and vacuuming (Dave and Ghaly 2011). Each oil spill removal method faces its own challenges in oil spill removal.

Tan et al. (2021). "Oil spill clean-up with bio-sorbents," BioResources 16(4), 8394-8416. 
Although mechanical and chemical treatment are commonly used, they require higher cost. Mechanical treatment faces challenges under rough sea waves along with high wind velocity. Chemical treatment requires post-treatment such as dispersion to reduce toxicity effect on marine creatures (Alaa El-Din et al. 2018). In-situ burning releases carbon dioxide into the atmosphere upon combustion. This method is less applicable when the spilled oil forms a stable emulsion which consists of more than $25 \%$ of water, as such oil slicks are unable to be ignited (Mullin and Champ 2003). Bioremediation has many advantages in terms of environmental aspect and economic properties. However, the biodegradation rate of oil spill by the microorganisms depends on many factors such as concentration of oil, availability of other nutrients, environmental factors, as well as different activities of microorganisms. During the initial application of microorganism where the oil concentration is high, the biodegradation process shows undesirable result. Another major concern for this method is the time needed to clean up the oil spill (Dave and Ghaly 2011). While methods involve coagulation have high oil removal efficiency, they require high operating cost and they are labor intensive as complex operation are required. Some of these methods will generate a second source of pollutant (Wahi et al. 2013).

Oil spill sorbents are relatively insensitive to sea conditions, easy to use, and economic feasible (Al-Majed et al. 2012). There are two types of sorbent, namely natural and synthetic sorbents. Each type of sorbent has its disadvantage. Natural organic sorbents are very difficult to be collected and labor intensive because they will absorb some of the seawater. Many of the natural inorganic sorbent are loose material and can be difficult to be applied in windy conditions. Synthetic sorbents, which are sometimes modified into super-hydrophobic materials, can be suitable to be reused many times. However, many are chemically synthesized and not biodegradable. In addition, sorbent collection after oil sorption requires high manpower (Dave and Ghaly 2011). The oil-soaked absorbent will be disposed of by burning in an industrial incinerator. The density and viscosity of the oil normally will be altered after the weathering process. Sea conditions such as waves and currents will further disperse the oil slick will be further dispersed, changing their physical and chemical properties. Photo-oxidation of the oil will produce a variety of oxidized compounds which become more water-soluble (Rogowska and Namiesnik 2010).

Researchers are continually researching and modifying synthetic sorbents to improve their performance. For example, Kukkar et al. (2020) engineered carbon nanotube (CNT) materials to super-hydrophobic products such as CNT aerogel/sponge sorbents, which showed excellent oil sorption capacity ( 80 to $180 \mathrm{~g} / \mathrm{g}$ ) and can be reused up to 1000 cycles. Light hydrophobic sorbents can be synthesized to deal with the light oil in the oil spill. For example, cellulose/graphene aerogels show high sorption capacity against many types of oil, including light oil such as hexane (Mi et al. 2018). Therefore, it is crucial to synthesize sorbent that could deal with different oil compounds. Reduced graphene oxide (rGO) coated on porous polyurethane (PU) is a cost-effective and highly hydrophobic sorbent. It has been shown to be effective in cleaning up oil spill, reusable and can absorb various organic solvents (Zhu et al. 2016). However, sorbent is often used in small spills and needs to be combined with other methods. Once being used in oil absorption, they need to be removed from water and they are re-used, recycled, or disposed (Rengasamy et al. 2011a). As mentioned above, one of the problems for using sorbents is the collection after oil sorption. To ease in the collection process, the sorbents can be wrapped inside a net that will keep them afloat (Bayat et al. 2005). On the other hand, mixing of different oil removal techniques can be proposed. The advantages of booms are easy to handle and flexible for

Tan et al. (2021). "Oil spill clean-up with bio-sorbents," BioResources 16(4), 8394-8416. 8396 
towing. For example, fence booms and curtain booms can be used. However, the collected oil need further treatment. Sorbents could be applied together with booms to increase the oil spill cleanup efficiency (Dave and Ghaly 2011). Skimmers are applied in the area to recover the oil spill when there is a floating layer. To deal with the sea environment, oil spill sorbent can be applied in the targeted area. Elevating skimmers can be combined with sorbent for more effective and faster processing (Hoang et al. 2018).

\section{UTILIZATION OF PLANT FIBER AS OIL SPILL SORBENT}

\section{Application of Bio-sorbent in Oil Spill}

This section focuses on environmentally friendly natural sorbents. Natural sorbents can be classified into organic and inorganic sorbents. An example of an inorganic sorbent is a natural occurring mineral, such as perlite. Perlite is an environmentally friendly oil sorbent that shows good oil sorption capacity (Teas et al. 2001). On the other hand, organic sorbent can be further classified into animal origin and plant origin. Organic sorbents or bio-sorbents are gaining attention, as they have shown comparable oil sorption capacity with synthetic sorbents. They seem promising due to their feasibility and effectiveness, as no additional chemicals are needed to demulsify the oil (Wahi et al. 2013). Animal origin sorbents are obtained without harming their lives. For example, molting cuticle from tarantulas is being studied as a practical option for oil sorption. Based on average spider biomass per square meter, the global spider community has estimated that the spiders can produce 2 and 6 million tons of cuticle (depending on the frequency of molting) annually, and this waste material can be collected from 190,000 spider breeders worldwide. The oil sorption mechanism can be explained by physical trapping of crude oil drops via the brushlike structure of the cuticle. The irregular branched hairs trap and retain the crude oil. The presence of wax on the spider cuticle improves its hydrophobicity by promoting the action of van der Waals forces and other chemical interactions during the oil sorption (Machalowski et al. 2020).

Raw natural wool that shows high oil sorption capacity and good buoyancy is being tested for oil spill clean-up. Ciufu et al. (2019) obtained a sorption result of 2.66 to 11.89 $\mathrm{g} / \mathrm{g}$ using crude oil. The good performance of wool is linked with the natural covering of wool grease, lanolin. During oil sorption, a thin layer of oil will be retained on the wool fibers, making them more hydrophobic (Johnson et al. 1973). According to Choi and Moreau (1993), the presence of oleophilic wax on the wool fibers aid in the adsorption of oil onto it. Next, the scaly structure of wool forms a deposition area for the oil as well as forming capillary bridges between oil and fiber. The medulla honeycomb structure also provides an area for oil retention. Human hair (50 to $100 \mu \mathrm{m}$ diameter) shows good result in oil sorption. Human hair contains porous cortex, and its hydrophobicity varies with different type of hair. African origin hair has higher oil sorption capacity than Asian origin and European origin. It shows twice of oil sorption in comparison to the latter hair types. This is due to its coarse and spongy nature which contains more macro-pores. On the other hand, ground hair shows higher oil sorption capacity as its oil sorption surface area increased (Ifelebuegu et al. 2015). Researcher are researching different natural sorbent for oil spill removal as they are easily available. This reduces the usage of synthetic sorbent (Dave and Ghaly 2011). As heavier oil such as heavy crude oil can adhere to the sorbent easily regardless of natural or synthetic sorbent, natural sorbent can be used as greener alternative (Bayat et al. 2005). 


\section{Characteristics of Sorbent Material for Liquid Hydrocarbon Removal} Wettability and hydrophobicity

Natural fibers that are sourced from plants generally are more abundant and more sustainable. They are chemical-free, biodegradable, and some even show comparable density with synthetic sorbent. Many of the raw natural sorbents exhibit excellent sorption and they have been widely studied for the substitution of synthetic sorbent in oil spill. The most commonly investigated natural oil sorbents are kapok, milkweed fiber, sugarcane bagasse, rice husk, and various plant materials (Wahi et al. 2013). For example, cattail fiber and kapok fiber absorbed 827 and $1107 \mathrm{mg}$ oil /g sorbent respectively, compared to 1008 $\mathrm{mg}$ oil /g sorbent of polyester fiber (Khan et al. 2004). Other plant fibers that have been tested for oil spill treatment include cotton grass fiber (Suni et al. 2004), vegetable fibers (Annunciado et al. 2005), and straw biomass waste (Tijani et al. 2016).

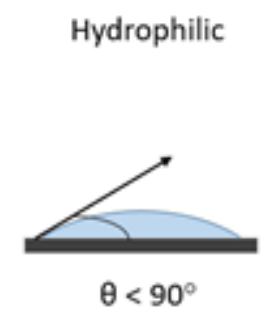

(a)

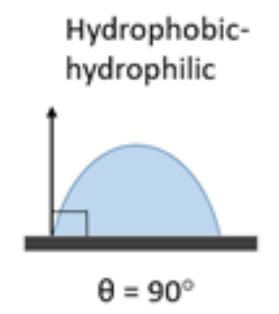

(b)

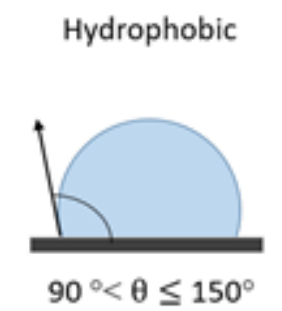

(c)

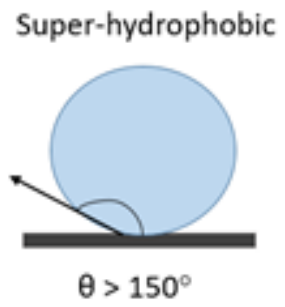

(d)

Fig. 1. Water contact angle on the fiber and its wettability (Doshi et al. 2018; Creative Commons CC-BY-NC-ND)

The wettability of water on the sorbent surface determines the oil sorption ability. Herein, wettability is measured by the water contact angle. The sorbent is considered as hydrophilic if the water droplet forms a contact angle on its flat surface that is less than $90^{\circ}$ (Fig. 1a). The sorbent is regarded to be intermediate-wet if the contact angle is equal to $90^{\circ}$ (Fig. 1b). For the contact angle between $90^{\circ}$ and $150^{\circ}$ (Fig. 1c), it is hydrophobic and if the contact angle exceeds $150^{\circ}$ (Fig. 1d), then the sorbent is considered as superhydrophobic. A sorbent with good hydrophobicity enhances the oil sorption capacity when water is present (Doshi et al. 2018). The finding of Lim and Huang (2007a) are consistent with this statement. The hydrophobic surface of kapok fiber is extracted and evenly deposited on a microscope glass. The contact angle for water droplet is observed to be $117^{\circ}$, whereas the contact angle for a diesel droplet is $13^{\circ}$. Kapok fiber is concluded to be oleophilic. Blue-colored water droplets are observed to form a large contact angle with the Calotropis gigantea fiber. The water droplets remain nearly spherical on the fibers with the contact angle of $129^{\circ}$; this represents excellent hydrophobic behavior (Zheng et al. 2016).

A hydrophobic natural sorbent encourages high sorption of oil in the oil-water environment. Natural hydrophobic fibers are associated with the presence of wax on the fiber surfaces (Khan et al. 2004; Dong et al. 2015). Wax present on the fiber surface promotes interaction between oil and fiber surface via hydrophobic interaction and van der Waals forces. According to Cui et al. (2012), the presence of surface wax on fiber repels water droplets and reduces the contact angle between oil droplets and fiber surface. This reduces the surface tension, which leads to minimum energy barrier for oil sorption. The importance of fiber wax can be seen in kapok fiber, as water cannot penetrate into its lumen. The large contact angle $\left(>90^{\circ}\right)$ between fiber wall and water forms negative capillary entry pressure and large surface tension against air in the lumen. This reduces the absorption of

Tan et al. (2021). "Oil spill clean-up with bio-sorbents," BioResources 16(4), 8394-8416. 8398 
water (Rengasamy et al. 2011a). Fibers such as sugarcane bagasse and rice husk that are lacking hydrophobic wax have high affinity for water sorption, thus reducing its oil sorption capacity. Rice husk after absorbing water even sunk to the bottom of container, thus eliminating its possibility to be used as sorbent in oil spill (Ali et al. 2012).

\section{Oil sorption mechanism}

Oil absorption has been mainly attributed to the capillary force via the lumen inside plant fibers (Lim and Huang 2007b). Fiber that shows good oil sorption capacity generally has hollow lumens, which act as the main site for capillary action to take place. A noncollapsing lumen such as the lumen in milkweed and kapok is essential for high oil sorption capacity. Choi and Moreau (1993) reported the movement of oil during oil sorption in plant fibers using ESEM micrographs. They eliminated other factors such as deposition or evaporation and confirmed that capillary action took place. Various researchers also confirmed that capillary action is the main sorption mechanism. Hydrophobic surfaces are the "promoter" of oil sorption. After diffusion of oil into the fiber via pores or lumen, capillary forces act as the main driving force (Dong et al. 2015; Fasanya et al. 2020; Haussard et al. 2003). Capillary forces are also responsible for the entrapment of oil inside the fiber, otherwise known as the oil retention capacity. There are three fractions of retention of oil in the fiber. The first oil fraction can be retained by weak capillary forces, but it is quickly released under gravitational force. The second oil fraction is retained by capillary force and can be retained under gravitational force. The third oil fraction is retained by capillary force and adsorptive force, which will not be released under gravitational and centrifugal forces (Cojocaru et al. 2011).

On the other hand, the viscosity of the oil has huge impact on the oil sorption performance. Oil with high viscosity adheres easily onto the surface of fiber (Choi and Cloud 1992). Higher oil viscosity leads to higher initial sorption ratio of the fiber. This is because viscous oil is heavier (with higher specific gravity) and are absorbed onto the fiber surface easily. Consequently, viscous oil also desorbs easily during the drainage period (Rengasamy et al. 2011a). However, this does not mean that plant fiber oil sorption performance is good in the case of a highly viscous oil spill. When oil viscosity increases, the oil sorption capacity of the fiber decreases. A more viscous oil decreases the sorption kinetics as capillary action is sensitive towards oil viscosity. Hence, the rate of oil sorption is different for each fiber, depending on the fiber natural properties (Deschamps et al. 2003). This finding is consistent with the findings of Cao et al. (2016). Their results indicate that more viscous oil spreads at a lower rate on the surface of plant fiber. In their research, the most viscous engine oil took the longest time to be completely adsorbed by cattail fiber. For the sorption kinetics, oil sorption speed is relatively higher at the initial phase. Then, it gradually decreases when the process reach sorption equilibrium. Thilagavathi et al. (2018) explained that small diameter pores are filled up first, which resulted in high initial sorption rate. Xu et al. (2019) concluded that the area of available sorption site decreases after some time, resulted in decreasing amount of oil uptake after the initial quick sorption period.

Adsorption capacity for oil spill uptake plays an important role in determining the oil sorption efficiency. The desorption isotherm of a volatile hydrocarbon, which can be determined gravimetrically, could provide some insights of the oil retention mechanism. Generally, capillary retained liquid has the tendency to evaporate faster than the adsorbed film of liquid. Rotaru et al. (2014) carried out benzene desorption isotherm analysis and reported that capillary action is the dominant sorption mechanism compared to adsorption in sorbent. This finding is consistent with the finding of Cojocaru et al. (2017). They carried 
out a cyclohexane desorption isotherm experiment to determine which mechanism has larger impact and concluded that capillary action is the dominant mechanism. Furthermore, most of the liquid retained by capillary forces can be removed by centrifugation or squeezing, while the liquid retained by adsorptive force cannot be removed by centrifugation. In natural plant fiber, adsorption takes place to a lesser degree. Researchers often modify plant fiber in order to increase the oil adsorption. Lv et al. (2018) modified the jute fiber by introducing $\mathrm{SiO}_{2}$ to the fiber surface. The modified fiber exhibited a higher specific area than raw fiber, which provided a higher adsorption area for oil. On the other hand, water adsorption capacity of fiber decreases. The similar trend is reported by Sidik et al. (2012). Compared to modified oil-palm leaves, the raw oil-palm leaves showed less adsorption of oil. FTIR spectra showed that untreated oil-palm leaves have less crude oil adsorption via less intensified peak across several regions. Adsorption capacity of plant fiber depends on the availability of fine fibrous structure forming the capillaries and sorbent surface structure (Angelova et al. 2011).

\section{Porosity and fiber structure}

Porosity plays important roles in oil sorption capacity. The oil sorption capacity is directly proportional to the porosity of a fiber, but only up to a certain extent. Capillary forces will be overcame by gravitational force in fiber with porosities larger than 0.98 (volume fraction of non-fiber), hence lowering the oil sorption capacity (Rengasamy et al. 2011b). By increasing the loose fiber assembly porosity up to 0.97 , the oil sorption capacity increases (Thilagavathi et al. 2018). Beside porosity, the surface structures of fiber play important roles in determining fiber oil sorption capacity. A rougher surface generally has higher retention capability of absorbed oil. Coarse surface on the fiber increases the surface area for adhesion of oil (Wang et al. 2013). The aquatic plant Salvinia sp. contains a large amount of hydrophobic fine hairs on its surface. The "hydrophobic space" in the hairs are able to penetrate into the water-oil emulsion while only allowing oil to break through this space (Ribeiro et al. 2003). In the case of cattail fiber, its cross-section looks like a belt that is contracted in the middle and protruded on both sides, or " $>--<$ ". Due to this special structure, cattail fiber has a larger surface area for absorption and retention of oil (Cui et al. 2012). Biomass biproducts such as fruit peel seem to have promising oil adsorption capacity, as their cellulose structure can retain the heavy oil such as lubricant oil and petrol oil (M. Abdullah et al. 2016). However, when it comes to reusability, natural fiber oil sorption capacity drops after the first absorption cycle. For example, there is still 20 to $23 \%$ oil trapped inside fiber lumen even after desorption. This causes the deformation of fiber structure as the inter-fiber distance is already contracted after the first oil sorption. Trapped oil also reduces the oil sorption capacity as they are still present in some of the lumens (Abdullah et al. 2010). Compared to synthetic sorbent, plant fiber oil sorption efficiency decreases with usage cycle. This is because the fiber structure is altered after tearing or crushing in the squeezing operation (Abdelwahab 2014).

\section{Retention Profiles}

Oil retention capacity is an important parameter in evaluating the sorbent. In many research articles the focus is on dynamic oil retention, oil retention, retention ratio, or retention profile. Chai et al. (2015) compared the weight of wet material to determine the oil retention capacity of different modified pomelo peel. The results indicated that the oil can be drained out faster initially before achieving equilibrium. According to Lim and Huang (2007b), oil on the external surfaces of the fiber has the tendency to drip out

Tan et al. (2021). "Oil spill clean-up with bio-sorbents," BioResources 16(4), 8394-8416. 8400 
instantaneously, and in the process of achieving equilibrium, extra-lumen liquid will be drained out slowly due to the insufficient capillary pressure holding against the weight of oil. Packing density affects the oil retention capacity of a fiber as higher packing density will result in higher oil retained in the fiber. Less viscous oil will be drained at a faster rate compared to more viscous oil, but it will achieve equilibrium earlier. Bazargan et al. (2015) proposed an equation to model the unsteady state loss of the liquid from the dripping sorbent. The instantaneous dripping of liquid is from the external surfaces of the sorbent. When the looser oil is drained, liquid released rate decreases along with stronger capillary forces. Rate of dripping also changes with the structure of the sorbent. Fibrous structure reduces the rate of release of liquid. In this proposed model, capillary force and sorbent structure are taken into account for the sorbent liquid retention. Research done by Radetic et al. (2008) is consistent with the model. The dripping liquid can be divided into three zones. In the first zone, the liquid retention drops the highest due to rapid liquid loss. In the second zone, the loss rate decreases while in the third zone, the liquid retention stabilizes. Similar oil retention curves are also reported by Al Zubaidi et al. (2016) and Rotaru et al. (2014). Wei et al. (2003) concluded that light oil tends to be released from sorbent faster with higher release rate compared to the heavy oil. High porosity sorbent has high oil sorption capacity but poor retention capacity. Fine fiber structure reduces the rate of release.

\section{Issues using Plant Fiber as Oil Spill Sorbent}

Most of the plant fiber will absorb water after some time. Plant fiber that is richer in cellulose and hemicellulose tends to be hydrophilic. The presence of $-\mathrm{OH}$ bonds in the cellulose will form hydrogen bonds with the water. Removal of this bond will alter the fiber characteristics, i.e. becoming more hydrophobic (Ramadevi 2012). Even hydrophobic fiber will eventually absorb water due to the presence of cellulose. Raw cotton that exhibits excellent oil sorption capacity sinks into water after being put in water for some time. Most of the natural fibers are partly hydrophilic and they are lacking stability in aqueous medium over time after oil sorption (Deschamps et al. 2003). Bagasse for example, has both hydrophilic and hydrophobic sites. Although the surface of bagasse is hydrophobic, its cellulosic pulp absorbs water when being put in water-oil mixture. It is observed that its amount of water absorbed increases with the increasing sorption time (Said Ael et al. 2009).

\section{Treatment to Enhance Hydrophobicity}

Cellulosic materials can be treated to acquire hydrophobic character. Common modification are chemical treatments such as sodium chlorite treatment, acetylation, mercerization, benzoylation, graft polymerization, enzymatic treatment, peroxide treatment, and plasma treatment (Ali et al. 2016). Herein, low cost, less chemical usage treatment methods are discussed as the goal is to produce cost effective and green sorbent for oil spill absorption.

\section{Chemical Treatment}

In acetylation, the $\mathrm{OH}$ bonds are reduced and replaced with ester bonds $(\mathrm{C}=\mathrm{O})$ and acetyl (C-O) bonds. The latter two bonds have higher hydrophobicity than the hydroxyl groups, which are available for hydrogen bonding with the water. The acetylation process of hydroxyl group turns the raw corn silk into better oil sorption sorbent by enhancing its hydrophobicity. The oil sorption capacity of modified corn increases and it can be reused up to five cycles (Liu et al. 2016). Teli and Valia (2013) used acetic anhydride with Nbromosuccinimide (NBS) (2\%) as catalyst in the acetylation of banana fiber. The cellulose

Tan et al. (2021). "Oil spill clean-up with bio-sorbents," BioResources 16(4), 8394-8416. 8401 
content of raw banana fiber was reduced from $57.64 \%$ to $50.61 \%$ and showed lower water sorption. Sugarcane bagasse, an agricultural waste was acetylated by introducing acetyl groups into the cellulose structure with acetic anhydride and NBS (1\%). The hydrophilicity of bleached softwood kraft fibers, on the other hand, can be reduced when these fibers are treated with lignin or alkenylsuccinic anhydride. The ability of such fibers to take up oil, even when wet by water, can be increased by treating them with these reagents (Payne et al. 2012).

Modified sugarcane bagasse has oil sorption capacity ranges from 13.5 to $20.2 \mathrm{~g} / \mathrm{g}$ and desorbs quickly when being squeezed (Sun et al. 2004). Mercerization is the treatment of fiber with alkali that break down the fibers bundle into smaller strain. This process often develops rougher surface topography for the fibers (Ali et al. 2016). According to Hasim et al. (2012), the changes of natural crystalline structure is dependent on the type of alkali and concentration used. Cellulose and other non-cellulose constituent such as hemicellulose, lignin, and pectin are removed. Anuzyte and Vaisis (2018) treated Rhytidiadelphus triquetrus (a moss species) with $\mathrm{NaOH}(5 \%)$ and observed that the oil (diesel) sorption capacity was increased by $22 \%$ after alkali treatment. The fiber surface became coarser, providing more surface area for oil sorption. Nevertheless, the removal of the cellulose component depends on the concentration of $\mathrm{NaOH}$. For example, increasing $\mathrm{NaOH}$ concentration in the alkali treatment increases the abaca hydrophobicity, resulting in lesser absorption of different types of water moisture (Ramadevi 2012).

\section{Grafting}

Grafting is a simple and effective method. Natural fiber can be modified by grafting oleophilic groups on the fiber for easier attachment of oil. This process will increase the hydrophobic properties of the fiber. Jarrah et al. (2018) modified cotton through silylation and increased its crude oil sorption capacity by more than two folds. The hydroxyl groups on cotton surface are turned into hydrophobic alkylsilyl ether chains. Huang et al. (2016) grafted epoxidized soybean oil (ESO) onto the surface of cellulose fiber through epoxide ring-opening polymerization process. The hydroxyl groups on the fiber are replaced with hydrophobic alkanes group. Other than that, cellulose fibers in its wet state can also be modified. Layered double hydroxide ( $\mathrm{LDH})$ is grafted into the wet, hydrophilic fibers so that organic groups can directly interact with the fiber via electrostatic interactions (Sobhana et al. 2017).

\section{Aerogel modification}

An aerogel is a solid porous material. Due to its high porosity (up to about $99 \%$ ) and high surface area (more than $100 \mathrm{~m}^{2} / \mathrm{g}$ ), such materials are good candidates for oil spill sorption. Aerogels can be made from inorganic source or biomaterials (Doshi et al. 2018). Herein, low-cost, degradable plant fiber with less chemical derived aerogels will be discussed. They are known as cellulose-based aerogels (CBA). Yin et al. (2017) used Eichhornia crassipes as the cellulose source and polyvinyl alcohol (PVA) as cross -linking agent to produce CBA. The results for its oil sorption capacity were 77.08 and $91.82 \mathrm{~g} / \mathrm{g}$ sorbent for crude oil and diesel oil, respectively, and it can be re-used up to 16 cycles. Thai et al. (2020) ground sugarcane bagasse before mixed with PVA, followed by freezing drying at $-70^{\circ} \mathrm{C}$. As sugarcane bagasse aerogel was still hydrophilic due to the presence of hydroxyl groups on its surface, it was further coated with methyltrimethoxysilane (MTMS). Lightweight, high porosity and hydrophobic twisted carbon fibers (TCF) are produced via 
pyrolysis of raw cotton. TCF can absorb oil from 50 to 190 times of its weight while remain floating on water surface after sorption of heptane (hydrocarbon) (Bi et al. 2013)

\section{High temperature treatment}

Hydrothermal treatment is an environmental friendly, simple, and cost effective method for the removal of hydrophilic cellulose components. Nordin et al. (2013) removed hemicellulose from palm fiber via superheated steam treatment. Anuzyte and Vaisis (2018) used hot water to modify the fiber surface. Higher contact surface area improves the adhesion of oil onto the modified fibers surface but also removes waxy coating and some other volatile components at the same time. Pyrolysis is another option in thermal treatment. Carbonized rice husk has better buoyancy and higher content of $\mathrm{SiO}_{2}$ oleophilic groups. However, the effect of pyrolysis depends on the natural content of the plant fiber (Angelova et al. 2011).

\section{UTILIZATION OF KENAF CORE FIBER AS OIL SPILL SORBENT}

\section{Kenaf Plant in Malaysia}

Kenaf (Hibiscus cannabinus L.) has been studied for the possibility of being used as a natural sorbent for oil spill removal. Kenaf plant is a traditional crop which has high concentration of fiber and is widely available. The Malaysian government even established research and development program to further exploit the commercial value of kenaf. For example, the National Kenaf and Tobacco Board (LKTN) promoted the plantation of local kenaf plant by allocating 2000 hectares of land for this purpose. They estimated that in year 2025, the demand for Kenaf is RM 3.5 billion (Habibu 2018).

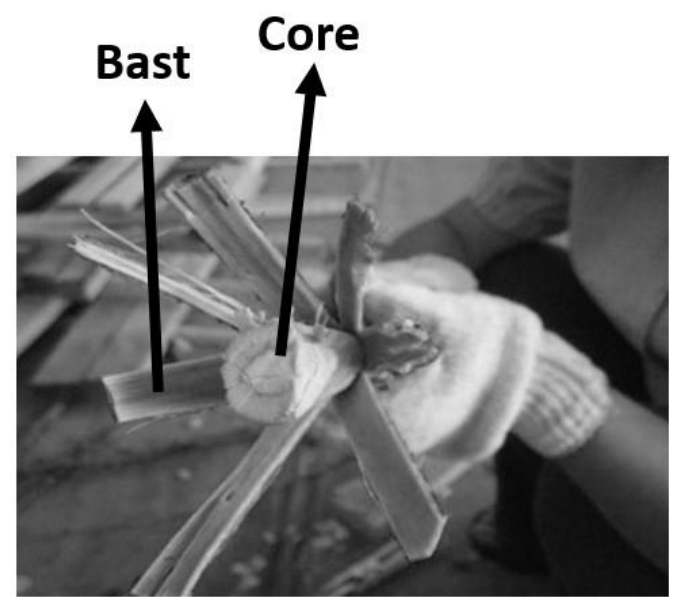

Fig. 2. Kenaf bast and core fiber

\section{Characteristics of Kenaf Bast and Core Fibers}

The two main fibers in kenaf are kenaf bast and kenaf core fibers. The bast fibers could be separated from the core fibers through two processes, which are decorticating and retting. Decorticating is the separation of the bast fiber from the core fiber using a decorticator. Retting is the separation of bast fiber from the core fiber through the facilitation of water or chemical soaking. The growth rate for kenaf bast fibers is higher than that of kenaf core fibers, which explains why bast fibers are relatively longer and 
stronger than core fiber (Kamal 2014). Malaysian kenaf consists of about $35 \%$ bast and $65 \%$ core. Its core and bast are rich in lignin and cellulose. Based on the properties of locally obtained kenaf stem, it can be deduced that kenaf core will generate more fibers in term of weight percentage, as kenaf core made up larger proportions of the kenaf stem (Abdul Khalil et al. 2010). Kenaf core is more woody compared to kenaf bast, as it contains more lignin. It is mainly used in absorbent applications, filler, animal bedding, and composites (Dilip 2004). The bast fiber, which is rich in cellulose content, is an important material for the paper manufacturing industry. It can be obtained in bundles and can be cut into specific length. Ashori (2006) obtained 45 to 51\% pulp yield through kraft pulping process using local kenaf fiber. The bast pulp has excellent density, tear index, as well as dry zero-span breaking length. Kenaf bast fiber is a promising material in the paper and pulp industry.

Table 1 \& 2. Characteristics and Properties of Kenaf Stems

\begin{tabular}{|l|l|c|c|c|}
\hline Characteristics/ Properties & & Bast fiber & Core fiber \\
\hline Proportion (\%) & $\begin{array}{l}\text { Cross-section } \\
\text { area }\end{array}$ & & 21.96 & 78.04 \\
\cline { 2 - 4 } & Dry Weight & & 32.2 & 68.5 \\
\hline Acidity $(\mathrm{pH})$ & & 7.13 & 5.21 \\
\hline Reference & & \multicolumn{2}{|c|}{ (Abdul Khalil et al. 2010) } \\
\hline
\end{tabular}

\begin{tabular}{|l|c|c|}
\hline & Bast fiber & Core fiber \\
\hline Cellulose (\%) & 59.8 & $37.6-49.0$ \\
\hline Lignin (\%) & 17 & $15.0-21.0$ \\
\hline Hemi Cellulose (\%) & 11.6 & - \\
\hline Ether Soluble Extract (\%) & 1.2 & - \\
\hline Cell Wall Contents & 10.4 & - \\
\hline Reference & \multicolumn{2}{|c|}{ (Dilip 2004) } \\
\hline
\end{tabular}

Abdul Khalil et al. (2010) carried out FT-IR analysis using local grown kenaf fiber. Peaks at 3390 and $1190 \mathrm{~cm}^{-1}$ indicate that there are $\mathrm{O}-\mathrm{H}$ stretching and $\mathrm{O}-\mathrm{H}$ bending frequencies. Peak at $2910 \mathrm{~cm}^{-1}$ show there is $-\mathrm{CH}_{2}$ stretching. These peaks indicate the presence of hydroxyl group of cellulose, hemicelluloses, and lignin. Absorbance peaks in the range of 1739 to $1650 \mathrm{~cm}^{-1}$ indicate carbonyl stretching $(\mathrm{C}=\mathrm{O})$ in the acetyl group in hemicelluloses and aldehyde group in lignin.

\section{Studies on Absorption of Liquid Hydrocarbon using Kenaf Core Fibers as Sorbent Material}

Research done by other researchers

Studies on oil spill uptake can be carried out by using the basic standard method, ASTM F726: Standard Test Method for Sorbent Performance of Adsorbents. According to this standard method, 15 min of contact time between liquid and sorbent is suggested, while $15 \mathrm{sec}$ or $2 \mathrm{~min}$ are suggested for the dripping time. However, this standard is not that popular among researchers due to some of the shortcomings associated with the standard, which include the non-specified mesh size of net and large scale of sorbent needed (Bazargan et al. 2015). However, this standard method can be useful to provide a general insight on oil sorption capability of the kenaf core fibers. Studies have showed that kenaf core fibers has the ability to be used as oil spill sorbent, but the oil recovery is low. Anthony (1994) compared the absorption of oil (non-detergent oil) between kenaf core and bast

Tan et al. (2021). "Oil spill clean-up with bio-sorbents," BioResources 16(4), 8394-8416. 8404 
fibers at a sorption time of 10 minutes. The result shows that oil recovered (oil recovered from the sorbent by hand squeezing as a percent of oil absorbed) for kenaf core fiber is lesser than that of bast fiber. This can be explained by the absorbed and retained oil in kenaf core fiber. The first run for oil recovery of raw kenaf bast was $29.9 \%$, while for raw kenaf core it was 2.9\%. Lee et al. (1999) compared the oil sorption capacities of kenaf bast fiber and kenaf core fiber by manipulating the kenaf fiber's physical properties. For example, it is practical to refine them, extract them, and reduce their sizes. Kenaf core fiber shows better oil sorption capacity than that of kenaf bast fiber and smaller fiber size shows higher sorption capacity.

Table 3. Results of Experiment Conducted by Lee et al. (1999)

\begin{tabular}{|c|c|c|c|c|}
\hline Oil Type & $\begin{array}{c}\text { Refined Kenaf Bast } \\
(\mathrm{g} / \mathrm{g})\end{array}$ & $\begin{array}{c}\text { Refined Kenaf Core } \\
(\mathrm{g} / \mathrm{g})\end{array}$ & $\begin{array}{c}\text { Contact time } \\
(\mathrm{min})\end{array}$ & $\begin{array}{c}\text { Dripping time } \\
(\mathrm{min})\end{array}$ \\
\hline Oil/water & 1.54 & 2.74 & 10 & 1 \\
\hline Oil/pure & 7.08 & 7.16 & 10 & 1 \\
\hline & $\begin{array}{c}\text { Ground Kenaf Bast } \\
(\mathrm{g} / \mathrm{g})\end{array}$ & $\begin{array}{c}\text { Ground Kenaf Core } \\
(\mathrm{g} / \mathrm{g})\end{array}$ & $\begin{array}{c}\text { Contact time } \\
(\mathrm{min})\end{array}$ & $\begin{array}{c}\text { Dripping time } \\
(\mathrm{min})\end{array}$ \\
\hline Oil/water & 0.45 & 3.95 & 10 & 1 \\
\hline Oil/pure & 2.34 & 6.36 & 10 & 1 \\
\hline & $\begin{array}{c}\text { Extracted Kenaf } \\
\text { Bast }(\mathrm{g} / \mathrm{g})\end{array}$ & $\begin{array}{c}\text { Extracted Kenaf Core } \\
(\mathrm{g} / \mathrm{g})\end{array}$ & $\begin{array}{c}\text { Contact time } \\
(\mathrm{min})\end{array}$ & $\begin{array}{c}\text { Dripping time } \\
(\mathrm{min})\end{array}$ \\
\hline Oil/water & 0.31 & 2.69 & 10 & 1 \\
\hline Oil/pure & 8.15 & 7.94 & 10 & 1 \\
\hline
\end{tabular}

Oloruntoyin and Olayinka (2016) determined different oil sorption capacities by varying parameters such as particle size, plant genotypes, and type of kenaf fiber. Important parameters such as buoyancy and amount of oil retained were also recorded. The mixture of genotypes records higher oil sorption capacity than single genotype. The results are shown in Table 4.

Table 4. Results of Experiment Conducted by Oloruntoyin and Olayinka (2016)

\begin{tabular}{|c|c|c|c|c|c|}
\hline Product type & Buoyancy & $\begin{array}{c}\text { Sorption (g } \\
\text { sorbent/ g oil) }\end{array}$ & $\begin{array}{c}\text { Retention (g } \\
\text { sorbent/ g oil) }\end{array}$ & $\begin{array}{c}\text { Contact } \\
\text { time (hr) }\end{array}$ & $\begin{array}{c}\text { Dripping } \\
\text { time (hr) }\end{array}$ \\
\hline $\begin{array}{c}\text { Spun fiber (2-5 cm } \\
\text { particle length) }\end{array}$ & Sunk & 1.66 & 0.75 & 4 & 12 \\
\hline Powdered core & $\begin{array}{c}\text { Partially } \\
\text { floated }\end{array}$ & 3.00 & 2.61 & 4 & 12 \\
\hline $\begin{array}{c}\text { Rough core (1- } \\
1.2 \mathrm{~cm} \text { particle } \\
\text { length) }\end{array}$ & $\begin{array}{c}\text { Partially } \\
\text { floated }\end{array}$ & 1.76 & 1.56 & 4 & 12 \\
\hline $\begin{array}{c}\text { Milled core/milled } \\
\text { fiber mix } \\
\text { (unbagged) }\end{array}$ & Floated & 3.09 & 2.75 & 4 & 12 \\
\hline $\begin{array}{c}\text { Whole stem grinded } \\
\text { (20 mixed, bagged) }\end{array}$ & Floated & 8.16 & 5.56 & 4 & 12 \\
\hline $\begin{array}{c}\text { Whole stem grinded } \\
\text { (1 genotype, } \\
\text { bagged) }\end{array}$ & Floated & 6.83 & 6.31 & 4 & \\
\hline
\end{tabular}

According to Siwayanan et al. (2020), kenaf core fibers tends to absorb crude oil four times of its mass, and 20 mesh kenaf core fiber absorbed more crude oil than 40 mesh 
kenaf core fiber. In the published research, the longer the contact time of kenaf core fiber in the crude oil-seawater mixture, the lesser the absorption of oil by the kenaf core fiber. In contrast, the water sorption capacity increases when the contact time increases. The same trend is observed for both 20 and 40 mesh kenaf core fiber.

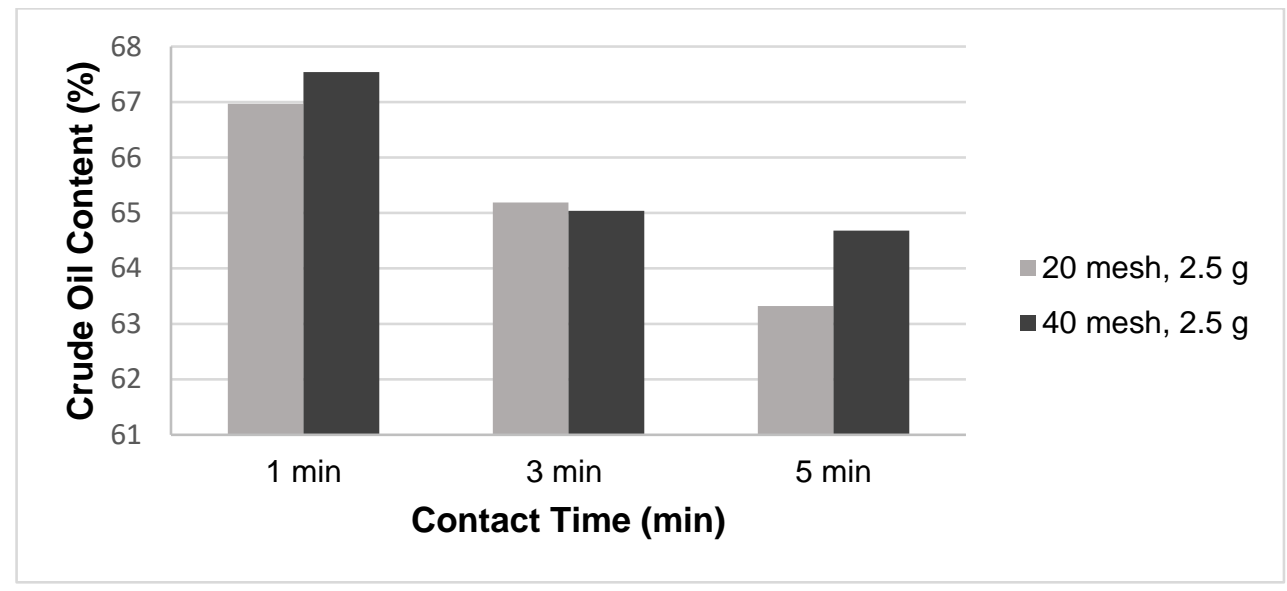

Fig. 3. Crude oil content (\%) for $2.5 \mathrm{~g}$ of 20 and 40 mesh kenaf core fibers at $1 \mathrm{~min}, 3 \mathrm{~min}$ and 5 min of contact time (Siwayanan et al. 2020; Creative Commons Attribution 3.0 licence)

\section{Result from researchers in Xiamen University Malaysia (XMUM)}

Oil sorption results for kenaf core fibers were obtained from experiments conducted by researchers in XMUM. Kenaf core fibers were either packed in a sachet for easier collection or ground into powder. The kenaf sachet and powder were placed in crude oil, seawater, and crude oil-seawater environments, respectively. The crude oil was obtained from a local refinery plant and seawater is obtained from a close-by sea. In seawater or crude oil environment alone, the maximum absorbed liquid started to appear at around 8 minutes. However, in oil and seawater mixture, prolonged contact time will increase the amount of seawater absorbed, but not the oil. Although 15 minutes of contact time is suggested by ASTM F726, the contact time was controlled at around 2 minutes as it is the optimum contact time of kenaf core fiber in a seawater-crude oil environment. The contact time was optimized in order to achieve the best oil sorption performance for kenaf core fiber.

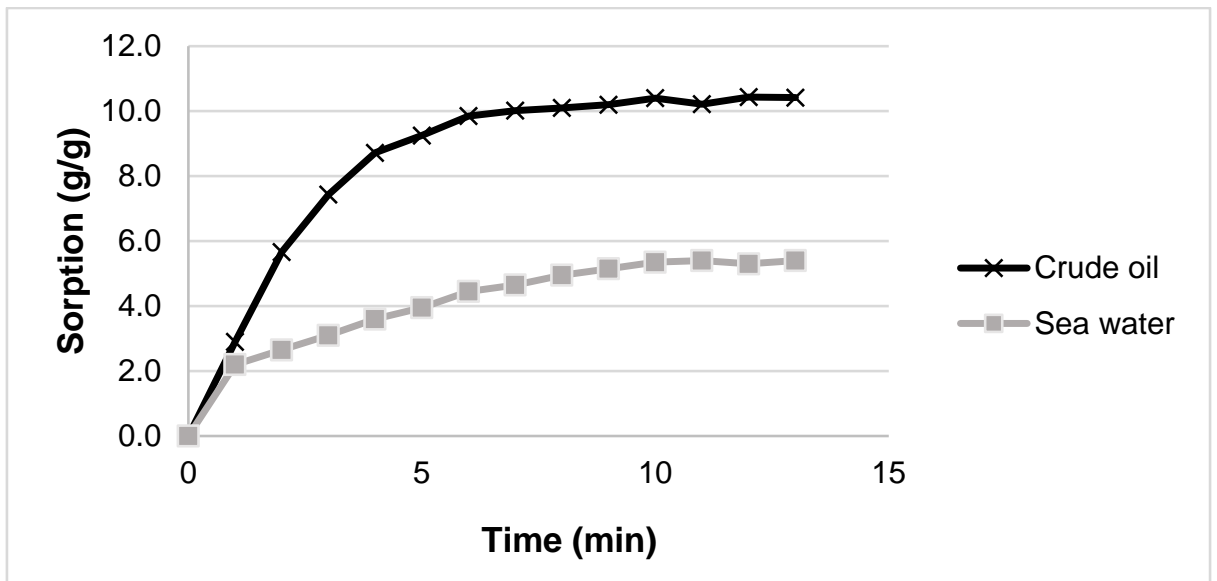

Fig. 4. Sorption capacity of kenaf core fiber against time 
Table 5. Result by XMUM Researchers

\begin{tabular}{|c|c|c|c|c|c|c|}
\hline & \multicolumn{2}{|c|}{$\begin{array}{c}\text { Water sorption capacity } \\
(\mathrm{g} / \mathrm{g})\end{array}$} & \multicolumn{2}{|c|}{$\begin{array}{c}\text { Oil sorption capacity } \\
(\mathrm{g} / \mathrm{g})\end{array}$} & \multirow{2}{*}{$\begin{array}{l}\text { Contact } \\
\text { time } \\
\text { (min) }\end{array}$} & \multirow[t]{2}{*}{$\begin{array}{l}\text { Dripping } \\
\text { time (s) }\end{array}$} \\
\hline & $\begin{array}{l}\text { Kenaf } \\
\text { sachet }\end{array}$ & $\begin{array}{l}\text { Kenaf } \\
\text { powder }\end{array}$ & $\begin{array}{l}\text { Kenaf } \\
\text { sachet }\end{array}$ & $\begin{array}{l}\text { Kenaf } \\
\text { powder }\end{array}$ & & \\
\hline $\begin{array}{l}\text { Crude oil } \\
\text { environment }\end{array}$ & $\mathrm{N} / \mathrm{A}$ & $\mathrm{N} / \mathrm{A}$ & 6.70 & 8.05 & 2 & 15 \\
\hline $\begin{array}{l}\text { Sea water } \\
\text { environment }\end{array}$ & 4.32 & 6.25 & $\mathrm{~N} / \mathrm{A}$ & $\mathrm{N} / \mathrm{A}$ & 2 & 15 \\
\hline $\begin{array}{l}\text { Crude oil- } \\
\text { seawater } \\
\text { environment }\end{array}$ & 2.60 & 5.10 & 3.60 & 1.40 & 2 & 15 \\
\hline
\end{tabular}

\section{Absorption Mechanism of Kenaf Core Fibers}

First, the oil will diffuse and attach onto the kenaf core fiber surface. After that, oil will accumulate in the pores or scaly/rough structures in the sorbent. As discussed before, the main challenge for natural sorbent is that they have high water uptake. Negative ionic charge due to dissociation of the carboxyl groups of the kenaf fiber, brought about by the $\mathrm{OH}^{-}$ions, will lead to swelling of fiber as well (Nosbi et al. 2011). The presence of wax on plant fiber enhances hydrophobic interaction between oil and the fiber (Wahi et al. 2013). The presence of wax on kenaf fiber has been verified through Soxhlet extraction using diethyl solvent (Abdul Khalil et al. 2010). Most of the hydrophobic substances will be dissolved in the solvent. Hence, it can be concluded that the presence of wax minimizes the surface tension and energy barrier for oil absorption (Abdullah et al. 2010). The internal capillary movement would be the main driving force for the absorption of oil within the plant fiber. The capillary action that occurred during oil sorption can be confirmed through SEM image analysis. The crude oil disrupts the orientation in the fiber wall, expanding the inter-fiber pores during absorption (Fig. 5) and resulted in the swelling effect of kenaf core fiber (Siwayanan et al. 2020).
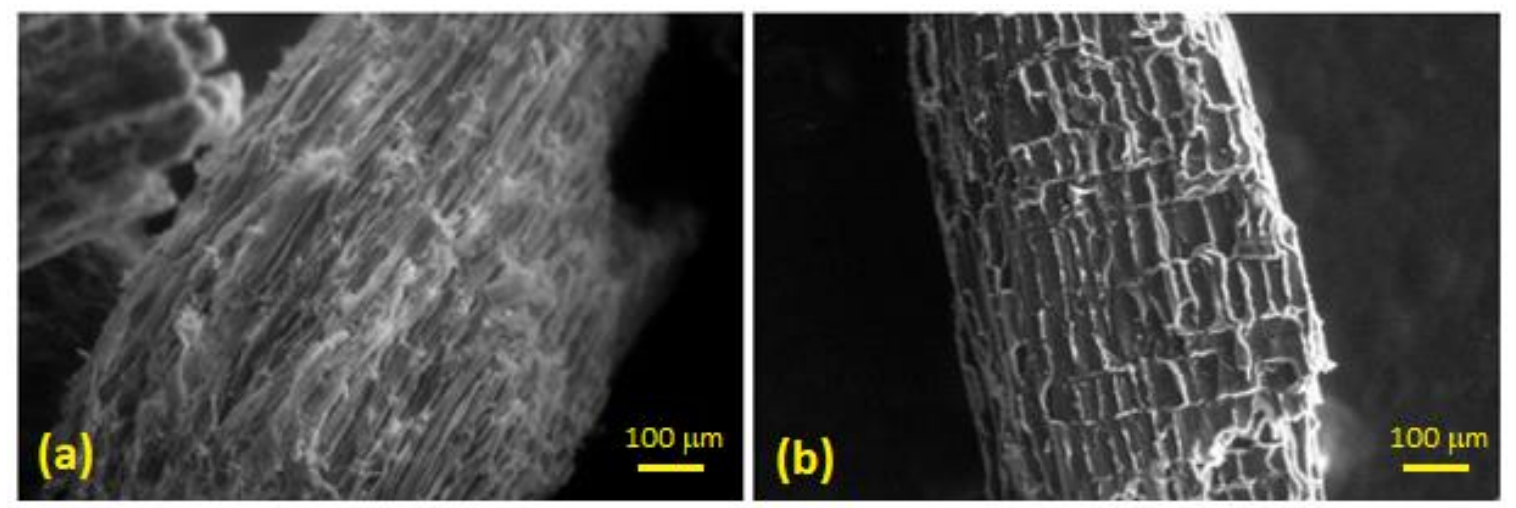

Fig. 5. (a) 20 mesh kenaf core fibers before and (b) after oil absorption, $\times 100$ magnification (Siwayanan et al. 2020; Creative Commons Attribution 3.0 licence)

Various studies discussed above showed that kenaf core fiber is a better sorbent than kenaf bast fiber for oil spill sorption. Kenaf bast fiber sank shortly after being put into the water bath, but kenaf core fiber remained floating throughout the experiment. This shows that kenaf core fiber has better buoyancy than kenaf bast fiber and can be easily applied and collected in oil spill environment. The differences in the buoyancy forces

Tan et al. (2021). "Oil spill clean-up with bio-sorbents," BioResources 16(4), 8394-8416. 8407 
between these two types of kenaf fibers can be attributed by their respective density, porosity, and absorption characteristics. Kenaf core fiber is rich in lignocelluloses components. The transverse section of the kenaf core fiber shows the presence of small hollow fibers and porous structure (Lips et al. 2009). This resulted in large absorption area. Cutting the dried kenaf core fiber into smaller pieces increases the exposed surface area. In other words, absorption and retention area are increased. Experimental results above showed that smaller kenaf core fibers have higher oil sorption capacity. From the results obtained from XMUM researchers, the kenaf core fiber seawater sorption capacity increases along with contact time. The presence of hydroxyl bonds facilitates in the absorption of water. It is important to control the contact time for oil spill sorption. This observation is consistent with the result of Siwayanan et al. (2020).

\section{Common Disposal Methods for Oil Absorbed Fiber}

Using non-buoyant materials as oil adsorbent could transfer the hazardous liquid to the sediment and threaten the food chain and ecosystem of the oil spill area. It is important to test the buoyancy of the sorbent. Only sorbent which passes the buoyancy test is suitable to be used as oil spill sorbent (Oloruntoyin and Olayinka 2016). Bio-sorbent sorption capacity decreases after reusing. The oil absorbed fiber is commonly squeezed, leading to structural damage of the sorbent. Unlike synthetic sorbent which can be reused many times, bio-sorbent such as kenaf core fiber has to be disposed after oil-spilled treatment. Incineration of the oil absorbed fiber could be done, but due to the presence of water in oilabsorbed fiber, evaporation is needed (Hubbe et al. 2013). Kenaf core fibers that are soaked with liquid hydrocarbon contain toxic hydrocarbon derivatives compounds such as benzene and polyaromatics. Upon disposing on the land, vapor-phase contamination could lead to odor issues. Over the time, hydrocarbon derivatives could leach directly into the soil and may contaminate groundwater. This might induce more cost to treat the polluted soil (Speight 2010). To evaluate the impacts of treatment of contaminated soil, multiple analysis would be required and this increases the analytical costs. It is difficult to formulate treatment strategies for the contaminated site to degrade the contaminant to safe level (Mrayyan and Battikhi 2005). Incineration of contaminated oil has many disadvantages, such as high operational cost due to requirement of high energy, large space, and environmental pollution (Okoh et al. 2019). Alternatively, composting of the polluted soil can be carried out. Composting involves biodegradation of the hydrocarbon contaminants in the soil using micro-organisms. This method has shown some proven viability but is restricted by the time needed and cost (Hubbe et al. 2013).

To recover the fuel value of oil, oil absorbed kenaf core fiber can be converted into fuel briquettes. In Malaysia, the government is promoting the use of biomass fuel briquettes in power generating plants (Chiew and Shimada 2013; Sing and Aris 2013). Kenaf fiber can be used as fuel for combustion in boilers, as it is rich in cellulose and lignin compounds (Saba et al. 2015). Kenaf core fiber powder after absorbing oil/ hydrocarbon compound in the petroleum-contaminated wastewater has the potential to be used as fuel. There is a research about utilizing kenaf fiber in water treatment. The sludge obtained after treatment is dewatered and dried, such that it can be used as biomass fuel (Tiemeyer 2005). Briquetting of the oil absorbed kenaf core fiber may require binder. Binder can adhere to the solid particles surfaces and generate strong bonds between the particles. Viscous binders harden and form solid bridges after cooling. Thin adsorbed binding layers can result in smoother layers, which will increase the particle contact area and decrease the inter-particles distances. As a result, the molecular bonding increases. Example of binders

Tan et al. (2021). "Oil spill clean-up with bio-sorbents," BioResources 16(4), 8394-8416. 8408 
are starch, lignin, resin, molasses lime and sodium bicarbonate. Proteins can be also used as binders, as they can be plasticized to increase the strength of the densified product. Example of protein binder derivatives are soybean meal, wheat, rye and barley (Kaliyan and Vance Morey 2009).

\section{CONCLUSION}

Plant fibers are gaining in popularity as potential adsorbents for oils, and there is an increasing demand for cheap and environmental friendly sorbents to clean up the oil spills in the sea. Some plant fibers show comparable oil sorption capacity to synthetic sorbent. The hydrophobicity of some plant fibers can be attributed to the presence of wax on their surfaces, porosity, and different type of fiber structures. However, due to the presence of hydroxyl groups, they will absorb water after some time in contact with water. Hence, less chemically intensive treatment methods can be considered to increase their hydrophobicity. Kenaf core fiber is easily available in Malaysia and it is suitable to be used as sorbent for oil spill. Results from various researches show that it has good oil sorption capacity. In summary, the cost and its oleophilicity make kenaf core fiber a suitable oil spill sorbent candidate.

\section{ACKNOWLEDGMENT}

This work was funded by Xiamen University Malaysia Research Fund (Grant no. XMUMRF/2019-C3/IENG/0012).

\section{REFERENCES CITED}

Abdel-Shafy, H. I., and Mansour, M. S. M. (2016). "A review on polycyclic aromatic hydrocarbons: Source, environmental impact, effect on human health and remediation," Egyptian Journal of Petroleum, 25(1), 107-123. DOI:10.1016/j.ejpe.2015.03.011

Abdelwahab, O. (2014). "Assessment of raw luffa as a natural hollow oleophilic fibrous sorbent for oil spill cleanup," Alexandria Engineering Journal, 53(1), 213-218. DOI:10.1016/j.aej.2013.11.001

Abdul Khalil, H. P. S., Yusra, A. F. I., Bhat, A. H., and Jawaid, M. (2010). "Cell wall ultrastructure, anatomy, lignin distribution, and chemical composition of Malaysian cultivated kenaf fiber," Industrial Crops and Products, 31(1), 113-121. DOI:10.1016/j.indcrop.2009.09.008

Abdullah, M., Muhamad, S. H. A., Sanusi, S. N., Jamaludin, S. I. S., Mohamad, N. F., and Rusli, M. A. H. (2016). "Preliminary study of oil removal using hybrid peel waste: Musa balbisiana and Citrus sinesis," Journal of Applied Environmental and Biological Sciences 6(8S), 59-63.

Abdullah, M. A., Rahmah, A. U., and Man, Z. (2010). "Physicochemical and sorption characteristics of Malaysian Ceiba pentandra (L.) Gaertn. as a natural oil sorbent," $J$. Hazard Mater. 177(1-3), 683-691. DOI:10.1016/j.jhazmat.2009.12.085

Tan et al. (2021). "Oil spill clean-up with bio-sorbents," BioResources 16(4), 8394-8416. 8409 
Aguilera, F., Mendez, J., Pasaro, E., and Laffon, B. (2010). "Review on the effects of exposure to spilled oils on human health," J. Appl. Toxicol. 30(4), 291-301. DOI:10.1002/jat.1521

Al-Majed, A. A., Adebayo, A. R., and Hossain, M. E. (2012). "A sustainable approach to controlling oil spills," J. Environ. Manag. 113, 213-227.

DOI:10.1016/j.jenvman.2012.07.034

Al Zubaidi, I. A. H., Al Tamimi, A. K., and Ahmed, H. (2016). "Remediation of water from crude oil spill using a fibrous sorbent," Environmental Technology \& Innovation, 6, 105-114. DOI:10.1016/j.eti.2016.08.002

Alaa El-Din, G., Amer, A. A., Malsh, G., and Hussein, M. (2018). "Study on the use of banana peels for oil spill removal," Alexandria Engineering Journal 57(3), 20612068. DOI:10.1016/j.aej.2017.05.020

Ali, A., Shaker, K., Nawab, Y., Jabbar, M., Hussain, T., Militky, J., and Baheti, V. (2016). "Hydrophobic treatment of natural fibers and their composites-A review," Journal of Industrial Textiles 47(8), 2153-2183. DOI:10.1177/1528083716654468

Ali, N., El-Harbawi, M., Jabal, A. A., and Yin, C.-Y. (2012). "Characteristics and oil sorption effectiveness of kapok fibre, sugarcane bagasse and rice husks: Oil removal suitability matrix," Environmental Technology 33(4), 481-486.

DOI:10.1080/09593330.2011.579185

Alonso-Alvarez, C., Perez, C., and Velando, A. (2007). "Effects of acute exposure to heavy fuel oil from the Prestige spill on a seabird," Aquat. Toxicol. 84(1), 103-110. DOI:10.1016/j.aquatox.2007.06.004

Angelova, D., Uzunov, I., Uzunova, S., Gigova, A., and Minchev, L. (2011). "Kinetics of oil and oil products adsorption by carbonized rice husks," Chemical Engineering Journal 172(1), 306-311. DOI:10.1016/j.cej.2011.05.114

Annunciado, T. R., Sydenstricker, T. H., and Amico, S. C. (2005). "Experimental investigation of various vegetable fibers as sorbent materials for oil spills," Mar. Pollut. Bull. 50(11), 1340-1346. DOI:10.1016/j.marpolbul.2005.04.043

Anthony, W. S. (1994). "Absorption of oil with cotton products and kenaf," Applied Engineering in Agriculture 10(3), 357-361. DOI:10.13031/2013.25864

Anuzyte, E., and Vaisis, V. (2018). "Natural oil sorbents modification methods for hydrophobicity improvement," Energy Procedia 147, 295-300.

DOI:10.1016/j.egypro.2018.07.095

Ashori, A. (2006). "Pulp and paper from kenaf bast fibers," Fibers and Polymers 7(1), 26-29. DOI:10.1007/bf02933598

Atlas, R. M., and Atlas, M. C. (1991). "Biodegradation of oil and bioremediation of oil spills," Current Opinion in Biotechnology 2(3), 440-443. DOI:10.1016/s09581669(05)80153-3

Balmer, J. (2014). "Seabird losses from Deepwater Horizon oil spill estimated at hundreds of thousands," ScienceMag.

Bayat, A., Aghamiri, S. F., Moheb, A., and Vakili-Nezhaad, G. R. (2005). "Oil spill cleanup from sea water by sorbent materials," Chemical Engineering \& Technology, 28(12), 1525-1528. DOI:10.1002/ceat.200407083

Bazargan, A., Sadeghi, H., Garcia-Mayoral, R., and McKay, G. (2015). "An unsteady state retention model for fluid desorption from sorbents," J. Colloid Interface Sci. 450, 127-134. DOI:10.1016/j.jcis.2015.02.036 
Bazargan, A., Tan, J., and McKay, G. (2015). "Standardization of oil sorbent performance testing," Journal of Testing and Evaluation 43(6). DOI:10.1520/jte20140227

Bi, H., Yin, Z., Cao, X., Xie, X., Tan, C., Huang, X., . . Z Zhang, H. (2013). "Carbon fiber aerogel made from raw cotton: A novel, efficient and recyclable sorbent for oils and organic solvents," Adv. Mater. 25(41), 5916-5921. DOI:10.1002/adma.201302435

Cao, S., Dong, T., Xu, G., and Wang, F. (2016). "Study on structure and wetting characteristic of cattail fibers as natural materials for oil sorption," Environ Technol, 37(24), 3193-3199. DOI:10.1080/09593330.2016.1181111

Chai, W., Liu, X., Zou, J., Zhang, X., Li, B., and Yin, T. (2015). "Pomelo peel modified with acetic anhydride and styrene as new sorbents for removal of oil pollution," Carbohydr Polym, 132, 245-251. DOI:10.1016/j.carbpol.2015.06.060

Chen, J., Zhang, W., Li, S., Zhang, F., Zhu, Y., and Huang, X. (2018). "Identifying critical factors of oil spill in the tanker shipping industry worldwide," Journal of Cleaner Production 180, 1-10. DOI:10.1016/j.jclepro.2017.12.238

Chiew, Y. L., and Shimada, S. (2013). "Current state and environmental impact assessment for utilizing oil palm empty fruit bunches for fuel, fiber and fertilizer - A case study of Malaysia," Biomass and Bioenergy 51, 109-124.

DOI:10.1016/j.biombioe.2013.01.012

Choi, H. M., and Cloud, R. M. (1992). "Natural sorbents in oil spill cleanup," Environmental Science \& Technology 26(4), 772-776. DOI:10.1021/es00028a016

Choi, H. M., and Moreau, J. P. (1993). "Oil sorption behavior of various sorbents studied by sorption capacity measurement and environmental scanning electron microscopy," Microsc. Res. Tech. 25(5-6), 447-455. DOI:10.1002/jemt.1070250516

Ciufu, A. G., Raducanu, C. E., Parvulescu, O. C., Cioroiu, D. R., and Dobre, T. (2019). "Natural wool for removal of oil spills from water surface," Revista de Chimie 70(11), 3977-3980. DOI:10.37358/rc.19.11.7685

Cojocaru, C., Dorneanu, P. P., Airinei, A., Olaru, N., Samoila, P., and Rotaru, A. (2017). "Design and evaluation of electrospun polysulfone fibers and polysulfone/NiFe2O4 nanostructured composite as sorbents for oil spill cleanup," Journal of the Taiwan Institute of Chemical Engineers 70, 267-281. DOI:10.1016/j.jtice.2016.11.005

Cojocaru, C., Macoveanu, M., and Cretescu, I. (2011). "Peat-based sorbents for the removal of oil spills from water surface: Application of artificial neural network modeling," Colloids and Surfaces A: Physicochemical and Engineering Aspects, 384(1-3), 675-684. DOI:10.1016/j.colsurfa.2011.05.036

Cui, Y., Xu, G., and Liu, Y. (2012). "Oil sorption mechanism and capability of cattail fiber assembly," Journal of Industrial Textiles 43(3), 330-337.

DOI: $10.1177 / 1528083712452902$

Dave, D., and Ghaly, A. E. (2011). "Remediation technologies for marine oil spills: A critical review and comparative analysis," American Journal of Environmental Sciences 7(5), 423-440.

Deschamps, G., Caruel, H., Borredon, M. E., Bonnin, C., and Vignoles, C. (2003). "Oil removal from water by selective sorption on hydrophobic cotton fibers. 1. Study of sorption properties and comparison with other cotton fiber-based sorbents," Environ. Sci. Technol. 37(5), 1013-1015. DOI:10.1021/es020061s

Dilip, M. Z. (2004). Absorbency Characteristics of Kenaf Core Particles, MS Thesis, NC State University, Raleigh, NC.

Tan et al. (2021). "Oil spill clean-up with bio-sorbents," BioResources 16(4), 8394-8416. 8411 
Dong, T., Wang, F., and Xu, G. (2015). "Sorption kinetics and mechanism of various oils into kapok assembly," Mar. Pollut. Bull. 91(1), 230-237.

DOI:10.1016/j.marpolbul.2014.11.044

Dong, T., Xu, G., and Wang, F. (2015). "Oil spill cleanup by structured natural sorbents made from cattail fibers," Industrial Crops and Products, 76, 25-33.

DOI:10.1016/j.indcrop.2015.06.034

Doshi, B., Sillanpaa, M., and Kalliola, S. (2018). "A review of bio-based materials for oil spill treatment," Water Res. 135, 262-277. DOI: 10.1016/j.watres.2018.02.034

Fasanya, O. O., Adesina, O. B., Okoduwa, U. J., Abdulkadir, J., Winful, E., Obidah, T. Y., Adamun, S. I., Audu, E. A., Myint, M. T. Z., Olabimtan, O. H., and Barminas, J. T. (2020). "Characterization of Sansevieria liberica \& Urena lobata fibers as potential sorbent materials for crude oil clean up," Journal of Natural Fibers 2020, 116. DOI: $10.1080 / 15440478.2020 .1788486$

Ferguson, A., Solo-Gabriele, H., and Mena, K. (2020). "Assessment for oil spill chemicals: Current knowledge, data gaps, and uncertainties addressing human physical health risk," Mar. Pollut Bull. 150, article no. 110746.

DOI:10.1016/j.marpolbul.2019.110746

Fingas, M. (2011). Oil Spill Science and Technology ( $1^{\text {st }}$ Ed.), Gulf Professional Publishing, United States.

Galieriková, A., and Materna, M. (2020). "World seaborne trade with oil: One of main cause for oil spills?," Transportation Research Procedia 44, 297-304. DOI:10.1016/j.trpro.2020.02.039

Habibu, S. (2018, July 15.). "Teresa Kok urges investments in eco-friendly kenaf industry," The Star.

Hasim, M. Y., Roslan, M. N., Amin, A. M., Ahmad Zaidi, A. M., and Ariffin, S. (2012). "Mercerization treatment parameter effect on natural fiber reinforced polymer matrix composite: A brief review," World Academy of Science, Engineering and Technology, 6(8). DOI:10.5281/zenodo.1059511

Haussard, M., Gaballah, I., Kanari, N., de Donato, P., Barrès, O., and Villieras, F. (2003). "Separation of hydrocarbons and lipid from water using treated bark," Water Research 37(2), 362-374. DOI:10.1016/s0043-1354(02)00269-5

Hoang, A. T., Pham, V. V., and Nguyen, D. N. (2018). "A report of oil spill recovery technologies," International Journal of Applied Engineering Research 13(7), 49154928.

Huang, X., Wang, A., Xu, X., Liu, H., and Shang, S. (2016). "Enhancement of hydrophobic properties of cellulose fibers via grafting with polymeric epoxidized soybean oil," ACS Sustainable Chemistry \& Engineering 5(2), 1619-1627. DOI:10.1021/acssuschemeng.6b02359

Hubbe, M. A., Rojas, O. J., Fingas, M., and Gupta, B. S. (2013). "Cellulosic substrates for removal of pollutants from aqueous systems: A review," BioResources 8(2), 30383097.

Ifelebuegu, A. O., Anh Nguyen, T. V., Ukotije-Ikwut, P., and Momoh, Z. (2015). "Liquid-phase sorption characteristics of human hair as a natural oil spill sorbent," Journal of Environmental Chemical Engineering 3(2), 938-943. DOI:10.1016/j.jece.2015.02.015

Jarrah, K., Hisaindee, S., and Al-Sayah, M. H. (2018). "Preparation of oil sorbents by solvent-free grafting of cellulose cotton fibers," Cellulose 25(7), 4093-4106. DOI:10.1007/s10570-018-1846-8

Tan et al. (2021). "Oil spill clean-up with bio-sorbents," BioResources 16(4), 8394-8416. 8412 
Johnson, R. F., Manjreker, T. G., and Halligan, J. E. (1973). "Removal of oil from water surfaces by sorption on unstructured fibers," Environ. Sci. Technol. 7(5), 439-443. DOI:10.1021/es60077a003

Kaliyan, N., and Vance Morey, R. (2009). "Factors affecting strength and durability of densified biomass products," Biomass and Bioenergy 33(3), 337-359.

DOI:10.1016/j.biombioe.2008.08.005

Kamal, I. B. (2014). "Kenaf for biocomposite: An overview," Journal of Science and Technology 6(2). Retrieved from https://publisher.uthm.edu.my/ojs/index.php/JST/article/view/796

Khan, E., Virojnagud, W., and Ratpukdi, T. (2004). "Use of biomass sorbents for oil removal from gas station runoff," Chemosphere 57(7), 681-689. DOI:10.1016/j.chemosphere.2004.06.028

Kukkar, D., Rani, A., Kumar, V., Younis, S. A., Zhang, M., Lee, S. S., Tsang, D. C. W., and Kim, K. H. (2020). "Recent advances in carbon nanotube sponge-based sorption technologies for mitigation of marine oil spills," J. Colloid Interface Sci. 570, 411422. DOI:10.1016/j.jcis.2020.03.006

Lee, B.-G., Han, J., S., and Rowell, R. M. (1999). "Oil sorption by lignocellulosic fibers," in: Kenaf Properties, Processing and Products, 423-433. Retrieved from https://www.fs.usda.gov/treesearch/pubs/5828

Lessard, R. R., and DeMarco, G. (2000). "The significance of oil spill dispersants," Spill Science \& Technology Bulletin 6(1), 59-68. DOI:10.1016/s1353-2561(99)00061-4

Lim, T.-T., and Huang, X. (2007a). "Evaluation of hydrophobicity/oleophilicity of kapok and its performance in oily water filtration: Comparison of raw and solvent-treated fibers," Industrial Crops and Products 26(2), 125-134.

DOI:10.1016/j.indcrop.2007.02.007

Lim, T. T., and Huang, X. (2007b). "Evaluation of kapok (Ceiba pentandra (L.) Gaertn.) as a natural hollow hydrophobic-oleophilic fibrous sorbent for oil spill cleanup," Chemosphere 66(5), 955-963. DOI:10.1016/j.chemosphere.2006.05.062

Lips, S. J. J., Iñiguez de Heredia, G. M., Op den Kamp, R. G. M., and van Dam, J. E. G. (2009). "Water absorption characteristics of kenaf core to use as animal bedding material," Industrial Crops and Products 29(1), 73-79.

DOI:10.1016/j.indcrop.2008.04.011

Liu, R., Dong, A., Fan, X., Yu, Y., Yuan, J., Wang, P., Wang, Q., and Cavaco-Paulo, A. (2016). "Enzymatic hydrophobic modification of jute fibers via grafting to reinforce composites," Appl. Biochem. Biotechnol. 178(8), 1612-1629. DOI:10.1007/s12010015-1971-x

Lv, N., Wang, X., Peng, S., Zhang, H., and Luo, L. (2018). "Study of the kinetics and equilibrium of the adsorption of oils onto hydrophobic jute fiber modified via the solgel method," Int. J. Environ. Res. Public Health 15(5). DOI:10.3390/ijerph15050969

Machalowski, T., Wysokowski, M., Petrenko, I., Fursov, A., Rahimi-Nasrabadi, M., Amro, M. M., Meissner, H., Joseph, Y., Fazilov, B., Ehrlich, H., and Jesionowski, T. (2020). "Naturally pre-designed biomaterials: Spider molting cuticle as a functional crude oil sorbent," J. Environ. Manage. 261, article no. 110218.

DOI:10.1016/j.jenvman.2020.110218

Mi, H.-Y., Jing, X., Politowicz, A. L., Chen, E., Huang, H.-X., and Turng, L.-S. (2018). "Highly compressible ultra-light anisotropic cellulose/graphene aerogel fabricated by bidirectional freeze drying for selective oil absorption," Carbon 132, 199-209.

DOI:10.1016/j.carbon.2018.02.033

Tan et al. (2021). "Oil spill clean-up with bio-sorbents," BioResources 16(4), 8394-8416. 8413 
Mishra, A. K., and Kumar, G. S. (2015). "Weathering of oil spill: Modeling and analysis," Aquatic Procedia 4, 435-442. DOI:10.1016/j.aqpro.2015.02.058

Mrayyan, B., and Battikhi, M. N. (2005). "Biodegradation of total organic carbons (TOC) in Jordanian petroleum sludge," J. Hazard Mater. 120(1-3), 127-134. DOI:10.1016/j.jhazmat.2004.12.033

Mullin, J. V., and Champ, M. A. (2003). "Introduction/overview to in situ burning of oil spills," Spill Science \& Technology Bulletin 8(4), 323-330. DOI:10.1016/s13532561(03)00076-8

Nordin, N. I., Ariffin, H., Andou, Y., Hassan, M. A., Shirai, Y., Nishida, H., . . Ibrahim, N. A. (2013). "Modification of oil palm mesocarp fiber characteristics using superheated steam treatment," Molecules 18(8), 9132-9146. DOI:10.3390/molecules18089132

Nosbi, N., Akil, H., Ishak, Z., and Bakar, A. (2011). "Behavior of kenaf fibers after immersion in several water conditions," BioResources 6(2), 950-960.

Okoh, E., Yelebe, Z. R., Oruabena, B., Nelson, E. S., and Indiamaowei, O. P. (2019). "Clean-up of crude oil-contaminated soils: bioremediation option," International Journal of Environmental Science and Technology 17(2), 1185-1198. DOI:10.1007/s13762-019-02605-y

Oloruntoyin, B. M., and Olayinka, R. A. (2016). "Effects of particle size, stem component and genotype on absorbency of kenaf (Hibiscus cannabinus L.) grown in Nigeria for oil-spill clean-up," Agricultural Sciences 07(09), 621-629. DOI:10.4236/as.2016.79058

Ossai, I. C., Ahmed, A., Hassan, A., and Hamid, F. S. (2020). "Remediation of soil and water contaminated with petroleum hydrocarbon: A review," Environmental Technology \& Innovation 17. DOI:10.1016/j.eti.2019.100526

Payne, K. C., Jackson, C. D., Aizpurua, C. E., Rojas, O. J., and Hubbe, M. A. (2012). "Oil spills abatement: Factors affecting oil uptake by cellulosic fibers," Environ. Sci. Technol. 46(14), 7725-7730. DOI: 10.1021/es3015524

Potenza, A. (2016, November 23). "The 2010 Deepwater Horizon oil spill caused widespread land erosion in Louisiana" The Verge.

Radetic, M., Ilic, V., Radojevic, D., Miladinovic, R., Jocic, D., and Jovancic, P. (2008). "Efficiency of recycled wool-based nonwoven material for the removal of oils from water," Chemosphere, 70(3), 525-530. DOI:10.1016/j.chemosphere.2007.07.005

Ramadevi, P., D. Sampathkumar, C.V. Srinivasa, and Bennehalli, B. (2012). "Effect of alkali treatment on water absorption of single cellulosic abaca fiber," BioResources 7(3), 3515-1524.

Rengasamy, R. S., Das, D., and Karan, C. P. (2011a). "Oil spill cleanup by structured fiber assembly," Indian Journal of Fiber \& Textile Research 36, 190-200.

Rengasamy, R. S., Das, D., and Karan, C. P. (2011b). "Study of oil sorption behavior of filled and structured fiber assemblies made from polypropylene, kapok and milkweed fibers," J. Hazard Mater. 186(1), 526-532. DOI:10.1016/j.jhazmat.2010.11.031

Ribeiro, T. H., Rubio, J., and Smith, R. W. (2003). "A dried hydrophobic aquaphyte as an oil filter for oil/water emulsions," Spill Science \& Technology Bulletin 8(5-6), 483489. DOI:10.1016/s1353-2561(03)00130-0

Rogowska, J., and Namiesnik, J. (2010). "Environmental implications of oil spills from shipping accidents," Rev. Environ. Contam. Toxicol. 206, 95-114. DOI:10.1007/9781-4419-6260-7_5 
Rotaru, A., Cojocaru, C., Cretescu, I., Pinteala, M., Timpu, D., Sacarescu, L., and Harabagiu, V. (2014). "Performances of clay aerogel polymer composites for oil spill sorption: Experimental design and modeling," Separation and Purification Technology 133, 260-275. DOI:10.1016/j.seppur.2014.06.059

Saba, N., Jawaid, M., Hakeem, K. R., Paridah, M. T., Khalina, A., and Alothman, O. Y. (2015). "Potential of bioenergy production from industrial kenaf (Hibiscus cannabinus L.) based on Malaysian perspective," Renewable and Sustainable Energy Reviews 42, 446-459. DOI:10.1016/j.rser.2014.10.029

Said Ael, A., Ludwick, A. G., and Aglan, H. A. (2009). "Usefulness of raw bagasse for oil absorption: a comparison of raw and acylated bagasse and their components," Bioresour. Technol. 100(7), 2219-2222. DOI:10.1016/j.biortech.2008.09.060

Sidik, S. M., Jalil, A. A., Triwahyono, S., Adam, S. H., Satar, M. A. H., and Hameed, B. H. (2012). "Modified oil palm leaves adsorbent with enhanced hydrophobicity for crude oil removal," Chemical Engineering Journal 203, 9-18. DOI:10.1016/j.cej.2012.06.132

Sing, C. Y., and Aris, M. S. (2013). "A Study of biomass fuel briquettes from oil palm mill residues," Asian Journal of Scientific Research 6(3), 537-545.

DOI:10.3923/ajsr.2013.537.545

Siwayanan, P., Ramachandran, D. G., Jamaluddin, R., and Ahmad, S. (2020). "Oil spill removal using kenaf core fibers as biosorbent material," IOP Conference Series: Materials Science and Engineering, 778. DOI:10.1088/1757-899x/778/1/012003

Sobhana, S. S. L., Zhang, X., Kesavan, L., Liias, P., and Fardim, P. (2017). "Layered double hydroxide interfaced stearic acid - Cellulose fibres: A new class of superhydrophobic hybrid materials," Colloids and Surfaces A: Physicochemical and Engineering Aspects 522, 416-424. DOI:10.1016/j.colsurfa.2017.03.025

Song, J., Lu, Y., Luo, J., Huang, S., Wang, L., Xu, W., and Parkin, I. P. (2015). "Barrelshaped oil skimmer designed for collection of oil from spills," Advanced Materials Interfaces 2(15). DOI:10.1002/admi.201500350

Speight, J. G. (2010). Handbook of Industrial Hydrocarbon Processes ( $1^{\text {st }}$ Ed.), Gulf Professional Publishing, United States.

Sun, X. F., Sun, R. C., and Sun, J. X. (2004). "Acetylation of sugarcane bagasse using NBS as a catalyst under mild reaction conditions for the production of oil sorptionactive materials," Bioresour. Technol. 95(3), 343-350.

DOI:10.1016/j.biortech.2004.02.025

Suni, S., Kosunen, A. L., Hautala, M., Pasila, A., and Romantschuk, M. (2004). "Use of a by-product of peat excavation, cotton grass fibre, as a sorbent for oil-spills," Mar. Pollut. Bull. 49(11-12), 916-921. DOI:10.1016/j.marpolbul.2004.06.015

Teas, C., Kalligeros, S., Zanikos, F., Stournas, S., Lois, E., and Anastopoulos, G. (2001). "Investigation of the effectiveness of absorbent materials in oil spills clean up," Desalination 140(3), 259-264. DOI:10.1016/s0011-9164(01)00375-7

Teli, M. D., and Valia, S. P. (2013). "Acetylation of banana fibre to improve oil absorbency," Carbohydr. Polym. 92(1), 328-333. DOI:10.1016/j.carbpol.2012.09.019

Thai, Q. B., Nguyen, S. T., Ho, D. K., Tran, T. D., Huynh, D. M., Do, N. H. N., . . Duong, H. M. (2020). "Cellulose-based aerogels from sugarcane bagasse for oil spillcleaning and heat insulation applications," Carbohydr. Polym. 228, article no. 115365. DOI:10.1016/j.carbpol.2019.115365

Thilagavathi, G., Praba Karan, C., and Das, D. (2018). "Oil sorption and retention capacities of thermally-bonded hybrid nonwovens prepared from cotton, kapok,

Tan et al. (2021). "Oil spill clean-up with bio-sorbents," BioResources 16(4), 8394-8416. 8415 
milkweed and polypropylene fibers," J. Environ. Manag. 219, 340-349.

DOI:10.1016/j.jenvman.2018.04.107

Tiemeyer, E. B. (2005). "Catalytic bioconversion of petroleum-contaminated wastes/wastewaters using kenaf core powder," U.S. Patent No. 7,157,000 B2.

Tijani, M. M., Aqsha, A., and Mahinpey, N. (2016). "Development of oil-spill sorbent from straw biomass waste: Experiments and modeling studies," J. Environ. Manag. 171, 166-176. DOI:10.1016/j.jenvman.2016.02.010

Villar, L., and Hamilton, M. (2017). "The Strait of Malacca, a key oil trade chokepoint, links the Indian and Pacific Oceans," <https://www.eia.gov/todayinenergy/detail.php?id=32452> (July 22 2020).

Wahi, R., Chuah, L. A., Choong, T. S. Y., Ngaini, Z., and Nourouzi, M. M. (2013). "Oil removal from aqueous state by natural fibrous sorbent: An overview," Separation and Purification Technology 113, 51-63. DOI:10.1016/j.seppur.2013.04.015

Wang, J., Zheng, Y., and Wang, A. (2013). "Coated kapok fiber for removal of spilled oil," Mar. Pollut. Bull. 69(1-2), 91-96. DOI:10.1016/j.marpolbul.2013.01.007

Wei, Q. F., Mather, R. R., Fotheringham, A. F., and Yang, R. D. (2003). "Evaluation of nonwoven polypropylene oil sorbents in marine oil-spill recovery," Marine Pollution Bulletin 46(6), 780-783. DOI:10.1016/s0025-326x(03)00042-0

Xu, Y., Su, Q., Shen, H., and Xu, G. (2019). "Physicochemical and sorption characteristics of poplar seed fiber as a natural oil sorbent," Textile Research Journal 89(19-20), 4186-4194. DOI:10.1177/0040517519829001

Yin, T., Zhang, X., Liu, X., and Wang, C. (2017). "Resource recovery of Eichhornia crassipes as oil superabsorbent," Mar. Pollut. Bull. 118(1-2), 267-274. DOI:10.1016/j.marpolbul.2017.01.064

Zheng, Y., Cao, E., Zhu, Y., Wang, A., and Hu, H. (2016). "Perfluorosilane treated Calotropis gigantea fiber: Instant hydrophobic-oleophilic surface with efficient oilabsorbing performance," Chemical Engineering Journal 295, 477-483. DOI:10.1016/j.cej.2016.03.074

Zhu, H., Chen, D., Yang, S., Li, N., Xu, Q., Li, H., Wang, L., He, J., Jiang, J., and Lu, J. (2016). "A versatile and cost-effective reduced graphene oxide-crosslinked polyurethane sponge for highly effective wastewater treatment," RSC Advances 6(44), 38350-38355. DOI:10.1039/c6ra05450a

Article submitted: June 29, 2021; Peer review completed: July 17, 2021; Revised version received and accepted: August 8, 2021; Published: August 20, 2021.

DOI: $10.15376 /$ biores.16.4.Tan 